\title{
Hematopoietic Stem Cell Potency for Cellular Therapeutic Transplantation
}

\author{
Karen M. Hall, Holli Harper and Ivan N. Rich \\ HemoGenix, Inc \\ U.S.A.
}

\section{Introduction}

Potency is the quantitative measurement of biological activity of a product (European Medicines Agency (EMA), 2008). Potency provides assurance that production and manufacture demonstrate consistency and provides information on stability and performance of the product. It also allows correlation with the clinical response and can help avoid product failure or toxicity due to the improper dose of the product being administered. For biopharmaceutical products such as drugs, growth factors and cytokines, vaccines etc., measurement of potency to predict dose has been a routine procedure for many years. Cells, on the other hand, are complex living entities that are continuously in flux. The potency of cells can change depending on numerous physiological and external environmental factors. Yet, with the increased number of cellular therapeutic applications and clinical regimen involving numerous cell types, the need to reliably and reproducibly measure biological and functional activity to meet the requirements of potency and ensure patient safety is of increasing importance (EMA, 2008; U.S. Food and Drug Administration, (FDA), 2011).

Determining the potency of a stem cell therapeutic can be a daunting task, especially if knowledge of the system biology, physiology and regulation is limited. In contrast, the hematopoietic system has proven to be not only an excellent model for stem cell biology, but also a model system for proliferation and differentiation in different applications. One of these applications is stem cell transplantation, a procedure that had its origins during the 1950s, became a quantitative assay in mice in 1961 (Till \& McCulloch), and a routine clinical procedure in the 1970s (Santos et al. 1972; Thomas et al. 1977; Santos, 1983) Since that time, the number of human bone marrow transplantations reached a peak in the late 1990s (National Marrow Donor Program (NMDP); Pasquini \& Wang, 2010) and has been declining to be replaced by alternative stem cell sources derived from mobilized peripheral blood (Haas et al. 1990; Koerbling et al. 1990; Sohn et.al. 2002) and umbilical cord blood (Broxmeyer et al. 1989; Gluckman et al. 1989).

Regardless of the tissue source, a successful transplant of stem cells is dependent upon the ability of the transplanted stem cells to lodge or "seed" in the bone marrow and begin the process of proliferation to produce lineage-specific progenitor cells. These differentiate into functionally mature circulating neutrophils, platelets and erythroid cells, the number of 
which provides information on the time at which engraftment took place. Proper lymphohematopoietic reconstitution occurs much later. The ability of the stem cells to engraft is dependent upon two primary factors. The first is the status and condition of the patient. The second is the proliferation ability and potential of the stem cells prior to being transplanted.

Proliferation ability is equivalent to the proliferation status of the stem cells at the time of testing. This parameter defines stem cell "quality". Proliferation potential, on the other hand, is the capacity or potential of the stem cells to proliferate. For a continuously proliferating system such as lympho-hematopoiesis, stem cell potential decreases from the most primitive to the most mature stem cells. Thus, the more primitive a stem cell, the greater its proliferation potential and therefore its potency. It follows that the primary goal of stem cell transplantation is to provide the patient with stem cells that exhibit varying degrees of proliferation potential or potency. In this way, the patient can be endowed with stem cells that provide both short- (Charbord, 1994; Civin et al. 1996; Leung et al. 1999; Zubair et al. 2006) and long-term (Civin et al. 1996; Leung et al. 1999; Zubair et al. 2006; Duggan et al. 2000) engraftment and reconstitution.

A product that is "balanced" to provide the correct amount of short- and long-term stem cell engraftment and reconstitution would be the ideal situation. Present technology is not, however, capable of measuring or delivering a "balanced" stem cell product. In many cases, the donor stem cell product is skewed towards a greater proportion of mature rather than primitive stem cells or visa versa. However, it is possible to quantitatively measure both stem cell quality and potency of representative stem cell populations to provide a reasonably good approximation of the overall quality and potency of the stem cell product. These parameters would then predict the potential of the stem cells to engraft and reconstitute the system.

In 2009, the U.S. Food and Drug Administration (FDA, 2009) designated umbilical cord blood as a drug because, when transplanted into a patient, it results in systemic effects. The consequence of this designation has meant that virtually every aspect from cord blood collection to transplantation must be validated and documented according to regulatory requirements. Included in this process are the tests and assays to monitor the procedures and characterize the product prior to use. Besides histocompatability testing, the most important parameter that should be measured just prior to the stem cell product being used is potency. The FDA guidance on potency for cellular therapeutic products specifically describes the regulations that define a potency assay as compliant (FDA, 2011). A potency assay must provide quantitative data demonstrating the biological activity of all "active ingredients" specific to the product. In the case of a stem cell product, the "active ingredients" are the stem cell themselves. The results must meet pre-defined acceptance and/or rejection criteria so that the test results provide information as to whether the product can be released for use. In addition, the assay(s) must include reference materials, standards and controls, since without these, the necessary validation parameters (accuracy, sensitivity, specificity, precision and robustness) cannot be measured and documented.

The present communication describes an in vitro assay that measures stem cell potency and quality and helps define release criteria for hematopoietic products derived from mobilized peripheral blood, umbilical cord blood or bone marrow. The assay was designed to comply with regulatory requirements. In the 3 -step process, all of the data required is accumulated 
in the initial stem cell culture and measurement step. The data obtained provides a degree of stem cell quality and potency assurance that has hitherto not been possible using the traditional methods of total nucleated cell count (TNC), viability and viable CD $34^{+}$counts, which provide no indication of stem cell functionality or growth. To illustrate the steps of the assay, a small number of mobilized peripheral blood samples are used to demonstrate the procedure for determining potency, quality and release criteria. A larger cohort of umbilical cord blood samples is then used to show the applicability of the assay.

The assay relies on two basic characteristics of stem cells, namely proliferation ability (quality) and potential (potency). It had been previously demonstrated that when hematopoietic stem cells were stimulated to proliferate in the presence of growth factors and cytokines, the intracellular ATP (iATP) concentration increased proportionately to the cell concentration plated (Rich \& Hall, 2005; Rich, 2007). The steepness or slope of the cell dose response was dependent upon the primitiveness and proliferation potential of the cells being examined. Stem cells have a greater proliferation potential than lineagespecific progenitor cells (Botnick e al. 1979). It would therefore be expected that the slope of the cell dose response would be steeper for stem cells than progenitor cells. In other words, the steeper the slope of the cell dose response, the greater the proliferation potential and the greater the potency. This biological phenomenon was incorporated into an assay that first estimates the potency ratio for two stem cell populations of a sample compared to a reference standard of the same material. The information obtained from the initial culture step was then used in the second step to substantiate the correlation between stem cell potency and quality. Finally, stem cell potency and quality were combined to determine release criteria of a sample. This information is provided when the iATP is released after culture by lysis of the cells. The iATP acts as a limiting substrate for the most sensitive, non-radioactive signal detection system available. This is a luciferin/luciferase reaction that produces bioluminescence, which is measured as light in a plate luminometer (Rich, 2003). The procedure and results described in this communication lay the foundation for future studies of stem cell potency and clinical outcome that might improve the risk of graft failure (Picardi \& Arcese, 2010; Querol et al. 2010) as well as safety and efficacy for the patient.

\section{Materials and methods}

\subsection{Cells}

Several cryopreserved, mobilized peripheral blood (mPB) samples from different donors were obtained from AllCells, Inc (Berkley, CA) in accordance with the company's Internal Review Board (IRB) approval. Vials of cryopreserved umbilical cord blood (UCB) samples were provided and released for research purposes by the University of Colorado Cord Blood Bank (ClinImmune, Inc) in Aurora, CO with approval by the respective Internal Review Board. Additional $\mathrm{mPB}$ and UCB cells were obtained from each source to use as internal reference standards.

\subsection{Reference standards (RS)}

The establishment of RSs is an absolute requirement for performing a potency assay. For hematopoietic cell-based therapeutics the number of cells obtained from a single donor UCB unit, $\mathrm{mPB}$ procedure or bone marrow aspirate are limited. This poses severe restrictions on 
establishing cellular reference standards. From a practical viewpoint, there are two alternatives. The first would be to establish multiple aliquots from several different donors that could be used as reference standards. Although each batch of RS would be expected to exhibit different biological activity and therefore different potency and quality characteristics, one batch would be designated as the primary RS. A second (donor specific) batch of cells would be tested against the primary RS and designated the secondary RS. Similarly, a third batch of cells would be tested against the secondary RS and designated the tertiary RS. The most recent batch of cells established as the RS would be used for every day testing until a new RS is established and tested. In this way it would always be possible to prepare a new RS and compare it against and established RS. The second alternative would be to assay a statistically significant number of samples of the same material to establish a range and mean/median potency that could be used as a "combined" RS for individual samples. This type of RS would take considerable time to establish. It would also require multiple laboratories to use the same standardized and validated assay so that results could be compared. The advantage would be that a "global" reference standard might be established for different cellular products that would allow comparison and calculation of potency ratios and quality of samples processed by individual laboratories. Release criteria for use in transplantation could also be established. The regulatory requirement for reference standards needed to measure cell potency is probably one of the most important aspects that has to be addressed by the different cellular therapeutic communities and standards organizations.

For the present study, the first alternative to establish reference standards was used. Cells designated as reference standards were prepared by separating the mononuclear cells (MNC) by density gradient centrifugation (see below), adjusting the cell concentration so that 1 million MNC were prepared in 7.5\% DMSO with 10\% fetal bovine serum (FBS) and medium in $1 \mathrm{ml}$. The cells were frozen in ampoules using an automated rate freezer and stored in liquid nitrogen (LN2).

\subsection{Preparation of cells for culture}

Cryopreserved cells were thawed in a $37^{\circ} \mathrm{C}$ water bath and the contents transferred to a tube containing 20mL of warmed Iscove's Modified Dulbecco's Medium (IMDM) supplemented with $10 \%$ FBS. After thawing and washing the cells once, followed by resuspension in $1 \mathrm{~mL}$ IMDM and $2 \%$ DNase, a cell count was performed on $20 \mu \mathrm{L}$ using a cell counter $(Z 2$, Beckman Coulter, Brea, CA). Another aliquot of $20 \mu \mathrm{L}$ was stained with 7-aminoactinomycin D (7-AAD, Beckman Coulter, Brea, CA) and the viability measured by flow cytometry using an EPICS $\mathrm{XL} / \mathrm{MCL}$ flow cytometer (Beckman Coulter, Brea, CA). Samples exhibiting viability below $85 \%$ were not used since cells either demonstrated poor proliferation or did not proliferate. The MNCs from each sample were fractionated on density gradient medium (Nycoprep 1.077, Axis-Shield, Accurate Chemicals and Scientific, Westbury, NY) by centrifugation for $10 \mathrm{~min}$ at $1,000 \times \mathrm{g}$ at room temperature (RT). The cells were washed in IMDM, centrifuged at $300 \times \mathrm{g}$ for $10 \mathrm{~min}$ at RT and resuspended in IMDM. This additional step removed the contaminating and dead cells and increased the viability to above $90 \%$. Since several internal studies indicated that 7-AAD could produce false positive results with respect to cell growth potential (data not shown), all samples were assessed for the production of iATP at 2,500, 5,000 and 7,500 cells/well to substantiate metabolic cell viability and functionality as described below. 


\subsection{In vitro cell culture of 2 stem cell populations to determine potency, quality and release criteria}

The instrument-based, ATP bioluminescence assay used to determine potency, quality and release (HALO-96 PQR, HemoGenix, Inc, Colorado Springs, CO) has been previously described in detail (Hall \& Rich, 2009). It is summarized here for completeness. In contrast to a previous study using cord blood cells and a methylcellulose assay format (Reems et al. 2008), the assay described below is a methylcellulose-free, 96-well culture system that incorporates Suspension Expansion Culture (SEC) technology (Rich, 2007; Hall \& Rich, 2009; Olaharski et al. 2009) for detecting both primitive (high proliferative potential stem and progenitor cells, HPP-SP) and more mature multipotential hematopoietic stem cells (colony-forming cell granulocyte, erythroid, macrophage megakaryocyte, CFC-GEMM). The assay was performed as follows. For each sample, the cell concentration was adjusted to $7.5 \times 10^{5}$ cells $/ \mathrm{mL}$ and a serial dilution performed in IMDM to produce $5 \times 10^{5}$ and $2.5 \times 10^{5}$ cells $/ \mathrm{mL}$. From each cell dilution, $0.1 \mathrm{~mL}$ was added to two separate tubes containing $0.9 \mathrm{~mL}$ of master mix, one for each stem cell population being determined. After mixing, $0.1 \mathrm{~mL}$ of the culture master mix was dispensed into 8 replicate wells of a 96-well plate to achieve the final concentrations of 2,500, 5,000 and 7,500 cells/well. The cocktail to stimulate CFC-GEMM consisted of erythropoietin, granulocyte-macrophage and granulocyte colony-stimulating factor, stem cell factor, thrombopoietin, Flt3-ligand and interleukins 3 and 6 . The cocktail to stimulate the HPP-SP stem cell population contained the same growth factors/cytokines as that for CFC-GEMM, but with the addition of interleukins 2 and 7 . The plates were incubated for 5 days at $37^{\circ} \mathrm{C}$ in a fully humidified incubator containing $5 \% \mathrm{CO}_{2}$ and $5 \% \mathrm{O}_{2}$ (Rich \& Kubanek, 1982).

\subsection{Assay calibration, standardization and sample processing}

Prior to measuring bioluminescence of the samples after culture incubation, an ATP standard curve was performed (Rich \& Hall, 2005; Reems et al. 2008; Hall \& Rich, 2009). Serial dilutions from a $10 \mu \mathrm{M}$ stock concentration were prepared so that the final dilutions were $5,1,0.5,0.1,0.05,0.01$ and $0.005 \mu \mathrm{M}$. In addition, an IMDM background and high and low ATP controls were included. Each dilution was dispensed into 4 wells $(0.1 \mathrm{~mL} /$ well $)$ of a 96-well plate. To each well, $0.1 \mathrm{~mL}$ of an ATP enumeration reagent containing a lysis buffer, luciferin and luciferase was added. The contents were mixed and the plate left to incubate for $2 \mathrm{~min}$ in a plate luminometer (SpectraMax L, Molecular Devices, Sunnyvale, CA) after which the bioluminescence was measured as light (photons). The resulting ATP standard curve was then used to automatically interpolate the output of the luminometer in relative luminescence units (RLU) into standardized ATP concentrations $(\mu \mathrm{M})$ using the instrument software (SoftMax Pro v5.4, Molecular Devices, Sunnyvale, CA). Inclusion of high and low controls in addition to the ATP standard curve allowed the assay to be calibrated and standardized. After performing the ATP standard curve, the sample plate(s) were removed from the incubator and allowed to attain room temperature. Thereafter, $0.1 \mathrm{~mL}$ of the ATP enumeration reagent was dispensed into each well and the contents mixed. After $10 \mathrm{~min}$ incubation in the instrument or in the dark, the bioluminescence was measured and the ATP concentrations automatically interpolated from the ATP standard curve. 


\subsection{Assay validation and statistics}

The ATP bioluminescence assay has been previously validated in accordance with bioanalytical method validation (FDA, 2001). For this specific application, the assay exhibited an accuracy (proportion of correct outcomes) of greater than $90 \%$. Sensitivity (proportion of correctly identified positive samples) and specificity (proportion of correctly identified negative samples) were determined using receiver operator characteristic (ROC) statistics (DeLong et al. 1985) in which the area under the curve (AUC) was determined for background (no stimulatory cocktail) versus CFC-GEMM and background versus HPP-SP. For the former, the AUC was 0.752 (95\% confidence intervals; 0.71-0.8; $p<0.0001$ ), while for the latter the AUC was 0.73 (95\% confidence intervals; 0.68-0.78, p<0.001). Since the AUC must be between 0.5 and 1 , the results demonstrated that the assay could differentiate between sensitivity and specificity. Assay precision (reliability and reproducibility) was performed on background, CFC-GEMM and HPP-SP over a cell dose range from 2,500 to 10,000 cells/well and demonstrated coefficients of variation (CV) of $15 \%$ or less. This was in compliance with regulatory requirements (FDA, 2011). Robustness, in this case transferability of the assay from one laboratory to another, had been previously reported (Reems et al. 2008). The results demonstrated a correlation coefficient (R) between laboratories of $0.94(\mathrm{p}<0.001)$.

Concentrations of ATP $(\mu \mathrm{M})$ are provided as the mean \pm 1 standard deviation of 8 replicate wells. The slope of the 3-point cell dose response was obtained from the linear regression using least squares analysis (Prism version 5, GraphPad Software, LaJolla, CA). For correlations, the slope of the linear regression, goodness of fit $\left(\mathrm{r}^{2}\right)$ and correlation coefficient (R) are reported. Tests of significance for correlation were performed using the Pearson twotailed test with an alpha of 0.05 .

\section{Results}

The procedure for determining stem cell potency, quality and release criteria is a 3-step process. However, only the first step requires cell culture and provides all the information for the remaining steps of the procedure. The culture step involves a 3-point cell dose response for two stem cell populations (CFC-GEMM and HPP-SP) for both the RS and samples.

\subsection{Step 1 - Measuring stem cell potency of mobilized peripheral blood}

The first step in the procedure is illustrated in Figure 1. This shows the cell dose responses for the mature multipotential stem cell, CFC-GEMM (Figs. $1 \mathrm{~A}$ and 1B), and the more primitive stem cell HPP-SP (Figs. 1C and 1D) from 4 different $\mathrm{mPB}$ samples cultured for 5 (Figs. 1A and 1C) and 7 days (Figs. 1B and 1D). The graphs demonstrate that an approximate 3 -fold increase in ATP concentration occurs within 2 days when the incubation time is increased from 5 to 7 days. A 7 day incubation period allows for increased assay sensitivity as well as the ability to perform the assay to accommodate a work schedule. Since the increase is cell dose dependent, it demonstrates that the assay is directly measuring an increase in the number of cells as a result of cell proliferation. It should be noted however, that although measurements at both 5 and 7 days are on the exponential part of the growth curve for both HPP-SP and CFC-GEMM, measurement of proliferation on day 7 will exhibit slightly greater coefficients of variation $(\mathrm{CVs})$ and will also include cells that have initiated differentiation. On day 5, little or no differentiation occurs (data not shown). 
A.

Potency of Mature Stem Cells (CFC-GEMM) Detected on Day 5

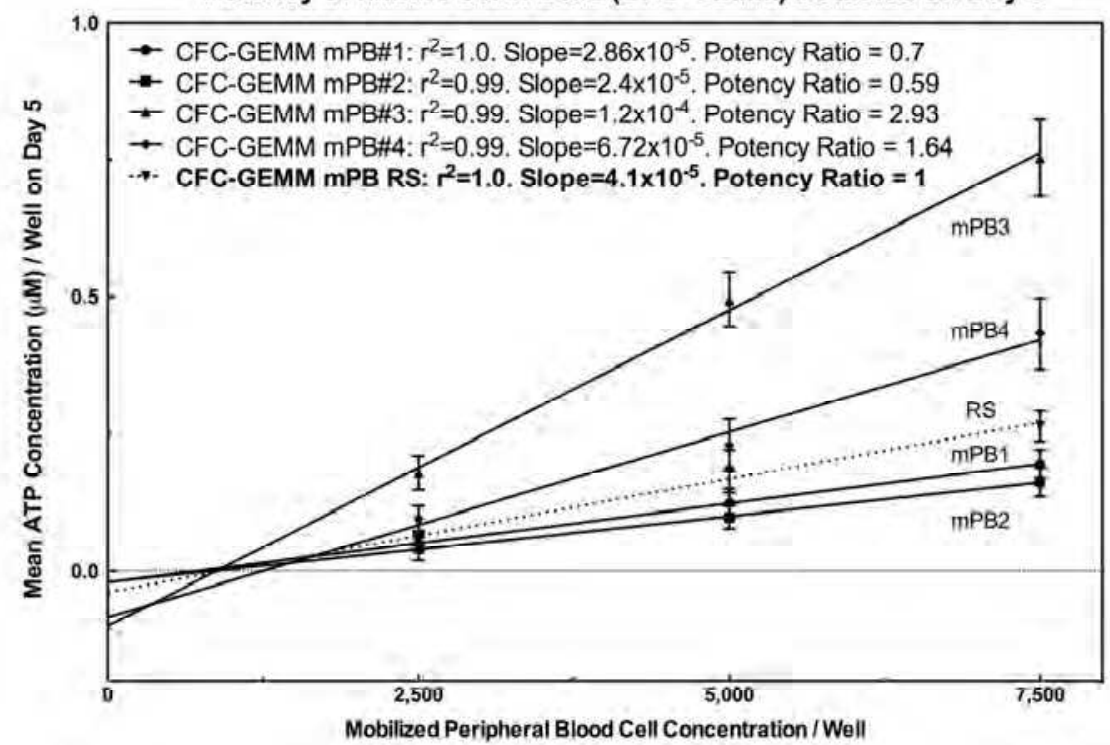

B.

Potency of Mature Stem Cells (CFC-GEMM) Detected on Day 7

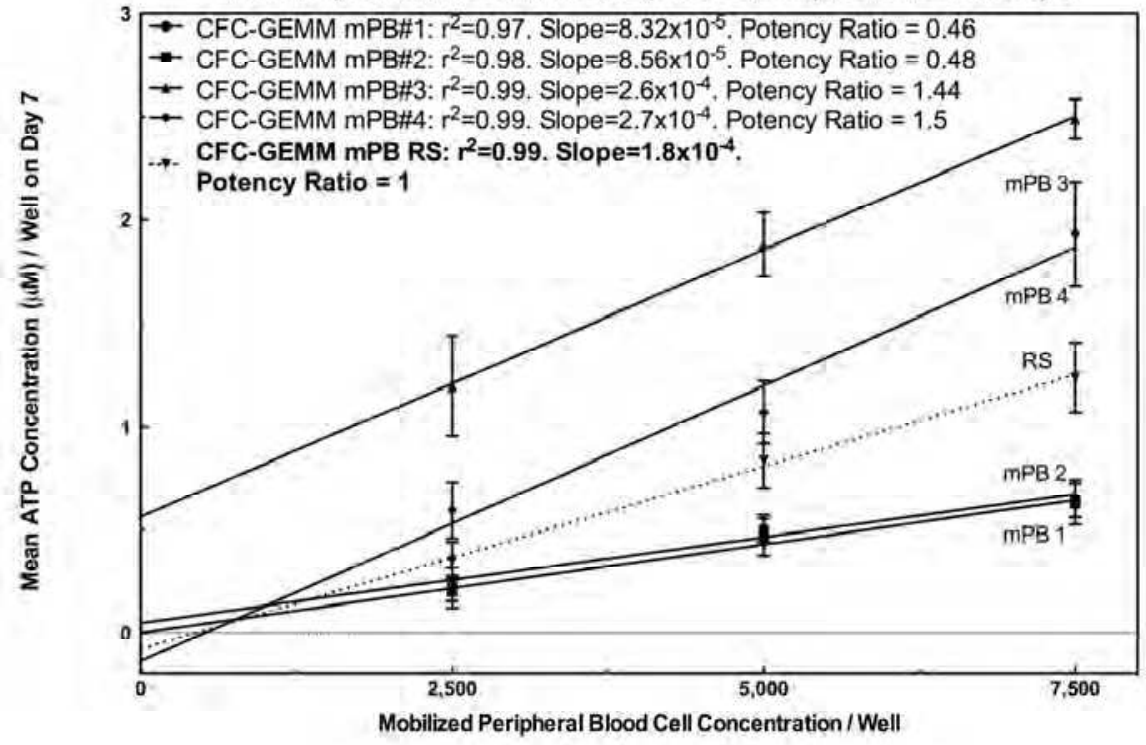

Fig. 1A and 1B. Measurement of Mobilized Peripheral Blood CFC-GEMM Stem Cell Potency on 5 and 7 Days of Culture. 
C.

Potency of Primitive Stem Cells (HPP-SP) Detected on Day 5

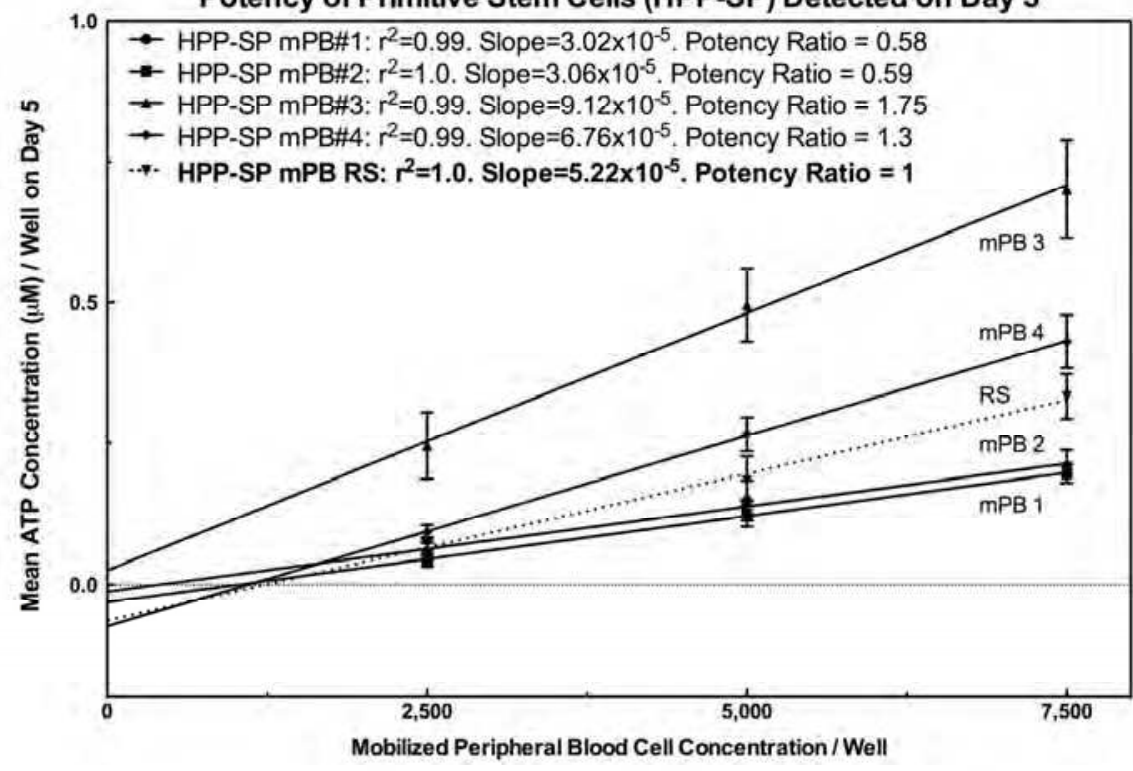

D.

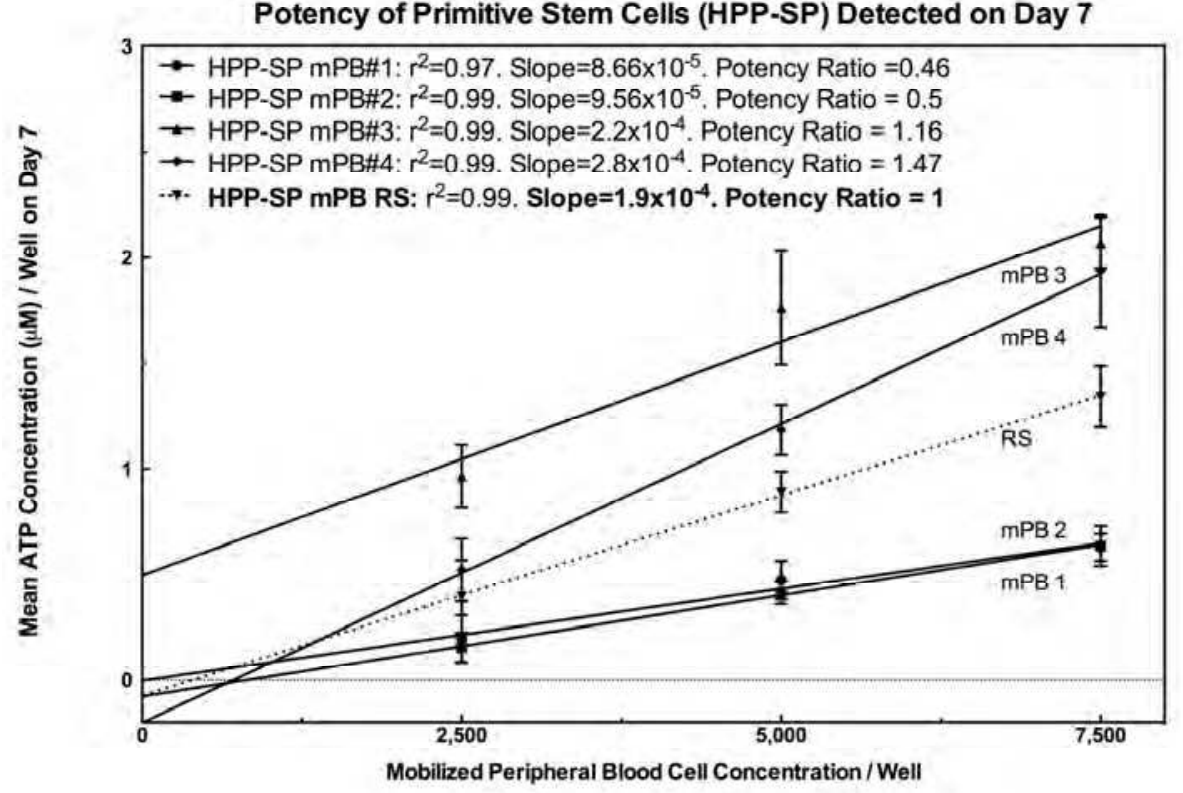

Fig. 1C and 1D. Measurement of Mobilized Peripheral Blood HPP-SP Stem Cell Potency on 5 and 7 Days of Culture. 
In addition to the samples, a mPB RS was also included and allows the potency ratio to be calculated as follows:

Potency Ratio = Slope of the sample linear regression / Slope of the RS linear regression.

The potency ratio therefore provides information on the dose required to obtain the same response as the RS. Since the potency of the RS is always 1, samples with a potency ratio less than 1 will require larger cell doses to produce the same response, while potency ratios greater than 1 will require fewer cells to produce the same response as the RS.

\subsection{Step 2 - The relationship between stem cell potency and quality}

The results in Fig. 1 illustrate two fundamental concepts that are necessary for measuring stem cell potency and quality. The first concept is that the slope of the cell dose response should be greater for the more primitive stem cells (HPP-SP) than for the mature hematopoietic stem cells (CFC-GEMM), since the former have greater proliferation potential than the latter. The slope of the cell dose response therefore provides a direct measurement of stem cell proliferation potential. The greater the proliferation potential, the greater the potency. Thus, the slope of the cell dose response is also a direct measurement of potency. The second concept, also illustrated in Fig. 1, shows that as the slope increases at a specific cell dose, there is a concomitant increase in ATP concentration. This is a measure of stem cell quality.

The result of combining these two concepts is shown in Figures 2A and 2B for CFC-GEMM and HPP-SP stem cell populations, respectively. The figures show that when the ATP concentration at a specific cell dose (in this case 5,000 cells/well) is plotted against the slope of the cell dose response linear regression for both stem cell populations cultured for either 5 or 7 days, there is a direct correlation between stem cell potency and quality. As a result, both stem cell potency and quality have to be taken into account to determine if the stem cell product conforms to specific, but arbitrary, acceptance values and can therefore be released for use.

\subsection{Step 3 - Using stem cell potency and quality to determine release criteria}

Figure $3 \mathrm{~A}$ and $3 \mathrm{~B}$ shows the ability of CFC-GEMM and HPP-SP to proliferate at 5,000 cells/well after 5 and 7 days of culture, respectively. It had previously been found that, after 5 days in culture, an ATP concentration below $0.04 \mu \mathrm{M}$ indicated that cells could not sustain proliferation. At 7 days, this threshold was increased to $0.12 \mu \mathrm{M}$. After 5 days of culture, the ATP concentration of samples 1 and 2 demonstrated minimal proliferation, but greater than the $0.04 \mu \mathrm{M}$ threshold. After 7 days of culture, proliferation of both samples had increased, together with samples 3 and 4 . If release criteria were based solely on stem cell quality or proliferation ability, it would be assumed that all 4 samples might be acceptable for release. However, Fig. 2 demonstrates that both stem cell quality and potency have to be considered as part of the release criteria.

Figure $3 \mathrm{C}$ shows the cumulative potency ratios of both CFC-GEMM and HPP-SP after 5 days and 7 days (Fig. 3D) in culture. Since the potency of the CFC-GEMM and HPP-SP reference standards is always 1, samples 1 and 2 exhibited potency ratios significantly less than the reference standard. In contrast, samples 3 and 4 exhibited both high stem cell quality and potency after 5 and 7 days of culture. Based on these results, mPB samples 1 and 2 would be sub-optimal or rejected, while samples 3 and 4 would be acceptable for use. 
A.

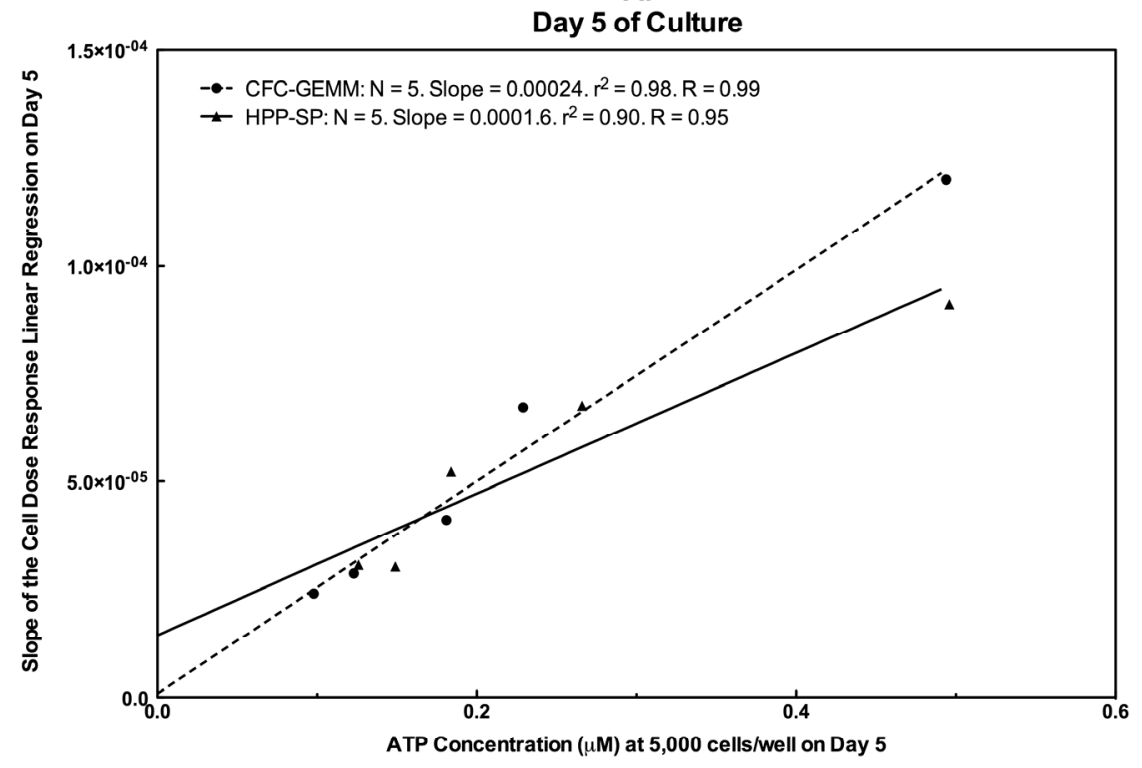

B.

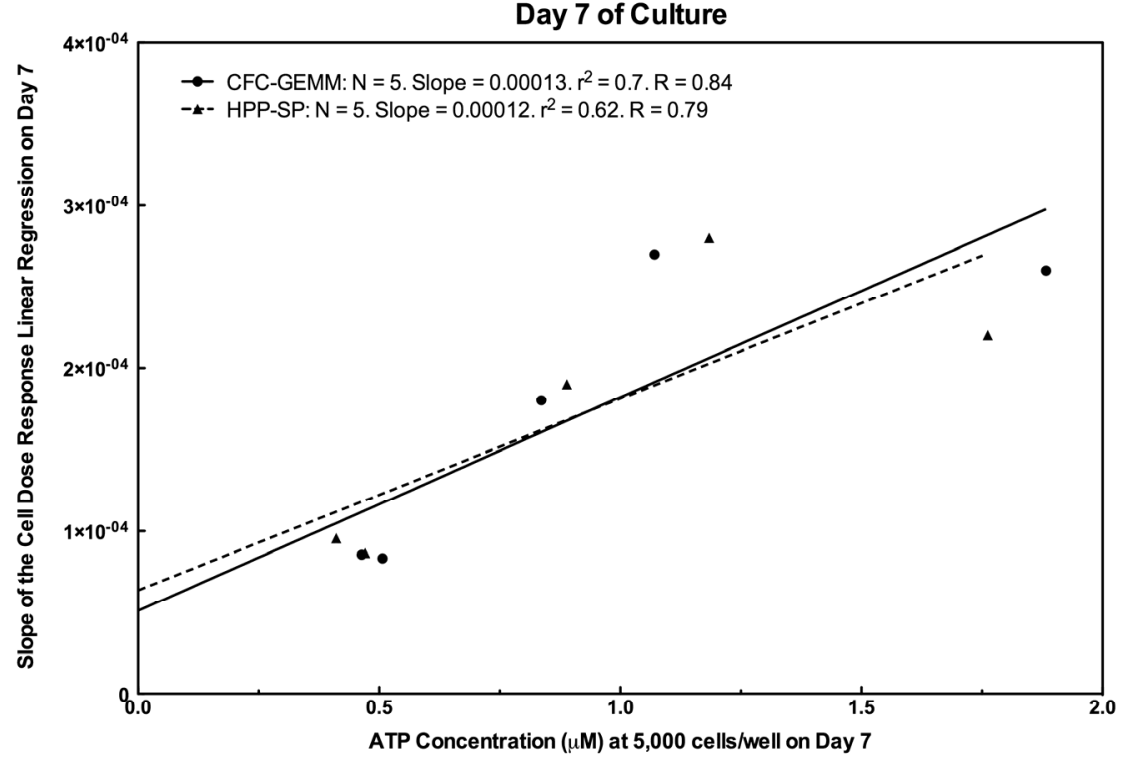

Fig. 2. Relationship Between Stem Cell Potency and Quality for Mobilized Peripheral Blood CFC-GEMM and HPP-SP Detected on Day 5 or 7 of Culture. 

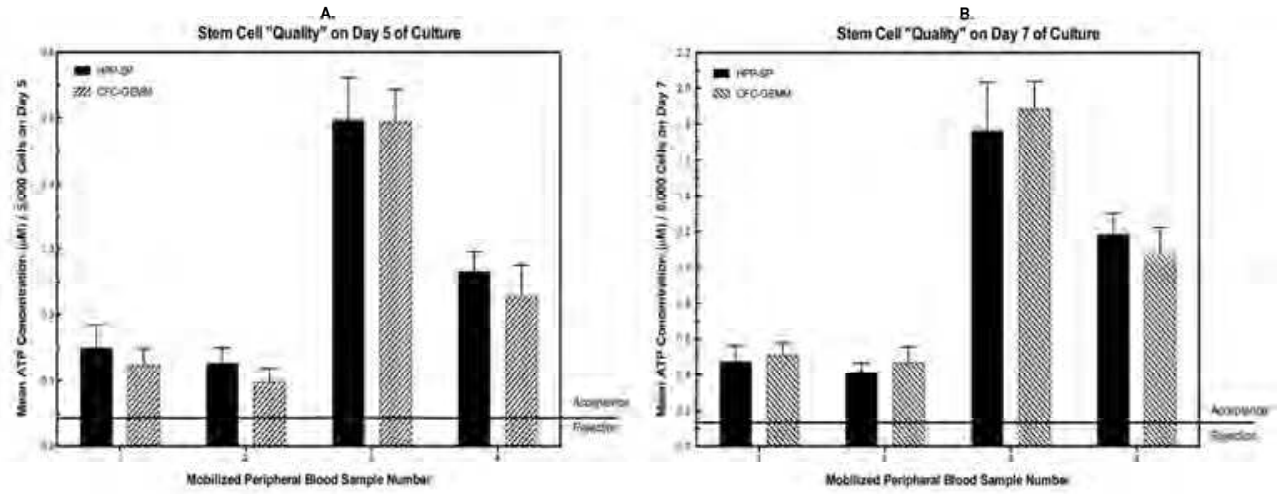

c.
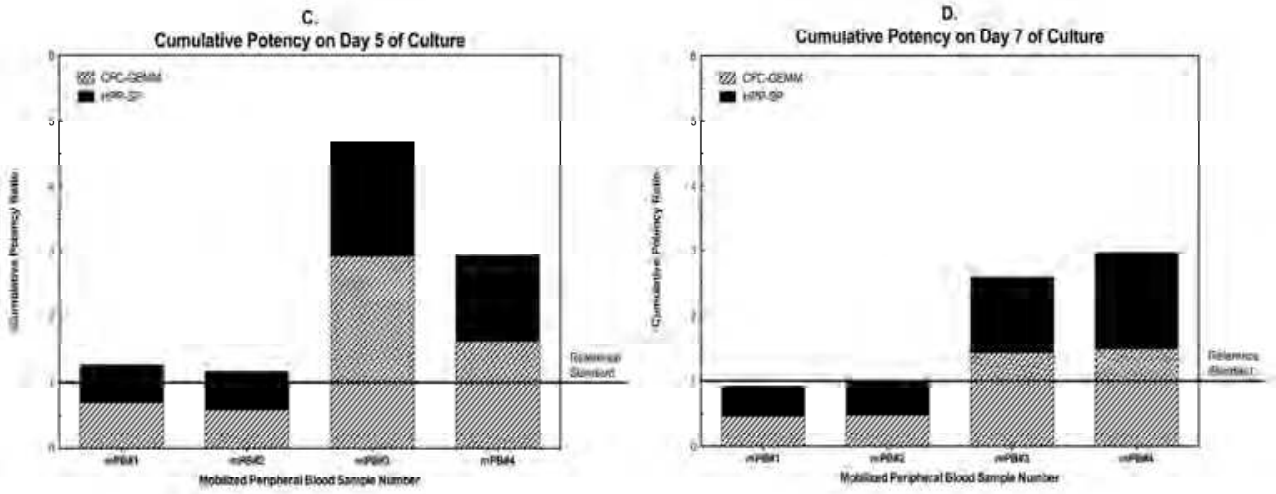

Fig. 3. Combining Mobilized Peripheral Blood Stem Cell Potency and Quality to Provide Release Criteria.

\subsection{Umbilical cord blood stem cell potency, quality and release and the relationship to engraftment potential}

A total of 28 UCB samples were analyzed for potency and quality using the same procedure described for $\mathrm{mPB}$ above, except that all assays were terminated after 5 days in culture, rather than performing both 5 and 7 day cultures. A 3-point cell dose response was performed for both the CFC-GEMM and HPP-SP stem cell populations and the slope of the linear regression was calculated for each cell dose response. The respective potency ratio for each CFC-GEMM and HPP-SP sample was then calculated using a UCB reference standard that was prepared from cord blood unit cells that did not meet the necessary criteria for storage. The slopes and potency ratios for each stem cell population are shown in Table 1. Also shown are the reported times to neutrophil and platelet engraftment. For one sample (sample 10), insufficient cells were obtained to perform a cell dose response for both stem cell populations. In two other samples (samples 18 and 25), insufficient cells were obtained after thawing to perform a HPP-SP stem cell dose response. 


\begin{tabular}{|c|c|c|c|c|c|c|}
\hline $\begin{array}{l}\text { Sample } \\
\text { Number }\end{array}$ & $\begin{array}{l}\text { Slope for } \\
\text { CFC- } \\
\text { GEMM }\end{array}$ & $\begin{array}{l}\text { Potency } \\
\text { Ratio for } \\
\text { CFC- } \\
\text { GEMM }\end{array}$ & $\begin{array}{l}\text { Slope for } \\
\text { HPP-SP }\end{array}$ & $\begin{array}{l}\text { Potency } \\
\text { Ratio for } \\
\text { HPP-SP }\end{array}$ & $\begin{array}{c}\text { Days to } \\
\text { Neutrophil } \\
\text { Engraftment } \\
(>500 / \mathrm{ul})\end{array}$ & $\begin{array}{c}\text { Days to } \\
\text { Platelet } \\
\text { Engraftment } \\
(>50 \mathrm{k} / \mathrm{ul})\end{array}$ \\
\hline 1 & 2.94E-05 & 2.91 & 2.23E-05 & 0.70 & 28 & 237 \\
\hline 2 & 3.14E-05 & 3.12 & 2.19E-05 & 0.69 & 14 & 2 \\
\hline 3 & $1.41 \mathrm{E}-05$ & 1.40 & $1.01 \mathrm{E}-05$ & 0.31 & 6 & 45 \\
\hline 4 & 2.09E-05 & 2.07 & 3.04E-05 & 0.95 & 30 & 49 \\
\hline 5 & 2.19E-05 & 2.18 & $2.59 \mathrm{E}-05$ & 0.81 & 17 & 39 \\
\hline 6 & $9.28 \mathrm{E}-06$ & 0.92 & $1.79 \mathrm{E}-05$ & 0.56 & 12 & 9 \\
\hline 7 & 2.25E-05 & 2.23 & 1.67E-05 & 0.52 & 17 & 45 \\
\hline 8 & $2.50 \mathrm{E}-05$ & 2.48 & $1.48 \mathrm{E}-05$ & 0.46 & 22 & 39 \\
\hline 9 & $1.52 \mathrm{E}-05$ & 1.50 & $9.70 \mathrm{E}-06$ & 0.30 & 56 & 13 \\
\hline 10 & IE & - & IE & - & 43 & 103 \\
\hline 11 & 1.77E-05 & 1.75 & 9.39E-06 & 0.29 & 34 & 7 \\
\hline 12 & 2.83E-05 & 2.81 & 1.99E-05 & 0.62 & 20 & 26 \\
\hline 13 & $1.09 \mathrm{E}-05$ & 1.08 & 7.43E-06 & 0.23 & NE & NE \\
\hline 14 & 8.12E-06 & 0.81 & $3.55 \mathrm{E}-06$ & 0.11 & 19 & 183 \\
\hline 15 & 6.69E-06 & 0.66 & 4.77E-06 & 0.15 & 31 & 122 \\
\hline 16 & $1.26 \mathrm{E}-05$ & 1.25 & $1.02 \mathrm{E}-05$ & 0.32 & 13 & 39 \\
\hline 17 & $1.81 \mathrm{E}-05$ & 1.80 & 1.90E-05 & 0.60 & 5 & 40 \\
\hline 18 & 3.07E-05 & 3.05 & IE & - & $\mathrm{NE}$ & $\mathrm{NE}$ \\
\hline 19 & 2.01E-05 & 1.99 & $4.45 \mathrm{E}-05$ & 1.39 & 27 & 38 \\
\hline 20 & $2.52 \mathrm{E}-05$ & 2.50 & $3.18 \mathrm{E}-05$ & 1.00 & 22 & 62 \\
\hline 21 & $1.54 \mathrm{E}-05$ & 1.53 & 3.30E-05 & 1.03 & 29 & 55 \\
\hline 22 & 2.31E-05 & 2.29 & $3.30 \mathrm{E}-05$ & 1.03 & 18 & 23 \\
\hline 23 & $1.20 \mathrm{E}-05$ & 1.19 & $1.70 \mathrm{E}-05$ & 0.53 & 28 & 70 \\
\hline 24 & $1.63 \mathrm{E}-05$ & 1.62 & 2.22E-05 & 0.70 & 15 & 46 \\
\hline 25 & $1.46 \mathrm{E}-05$ & 1.45 & IE & - & 26 & 39 \\
\hline 26 & $2.12 \mathrm{E}-05$ & 2.10 & 2.73E-05 & 0.85 & 28 & 61 \\
\hline 27 & 1.37E-05 & 1.35 & $1.74 \mathrm{E}-05$ & 0.54 & 37 & 126 \\
\hline 28 & $1.50 \mathrm{E}-05$ & 1.49 & $2.16 \mathrm{E}-05$ & 0.68 & 114 & 113 \\
\hline
\end{tabular}


A.

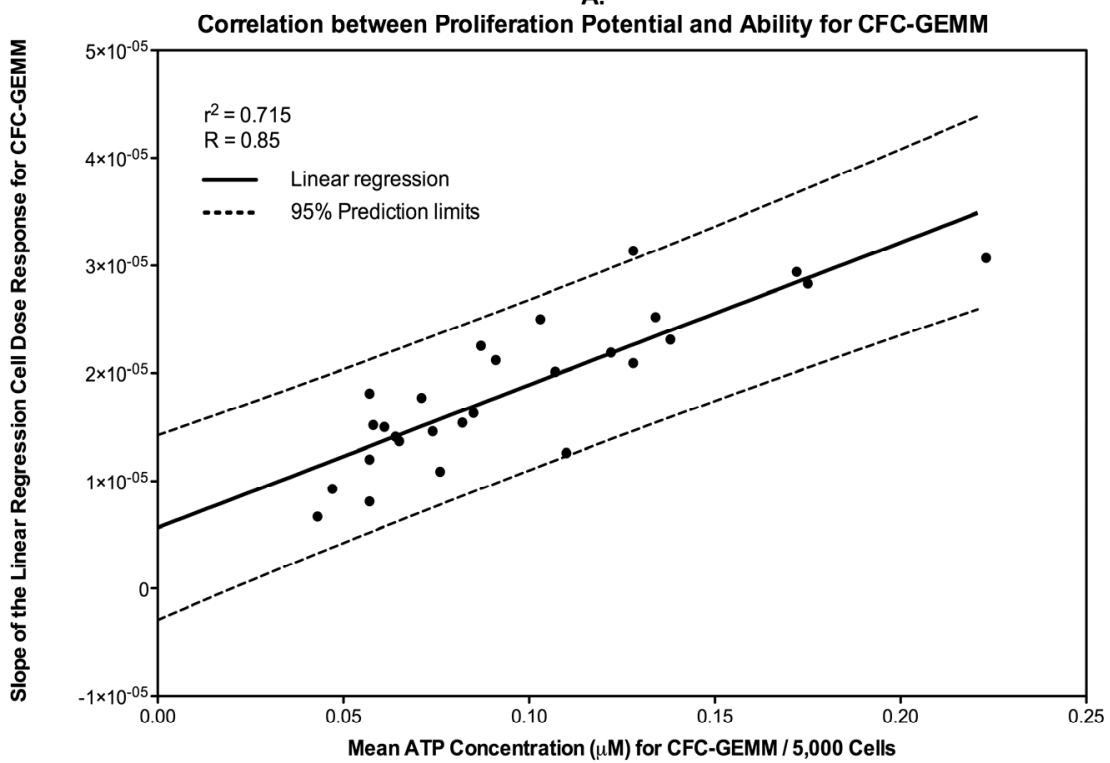

B.

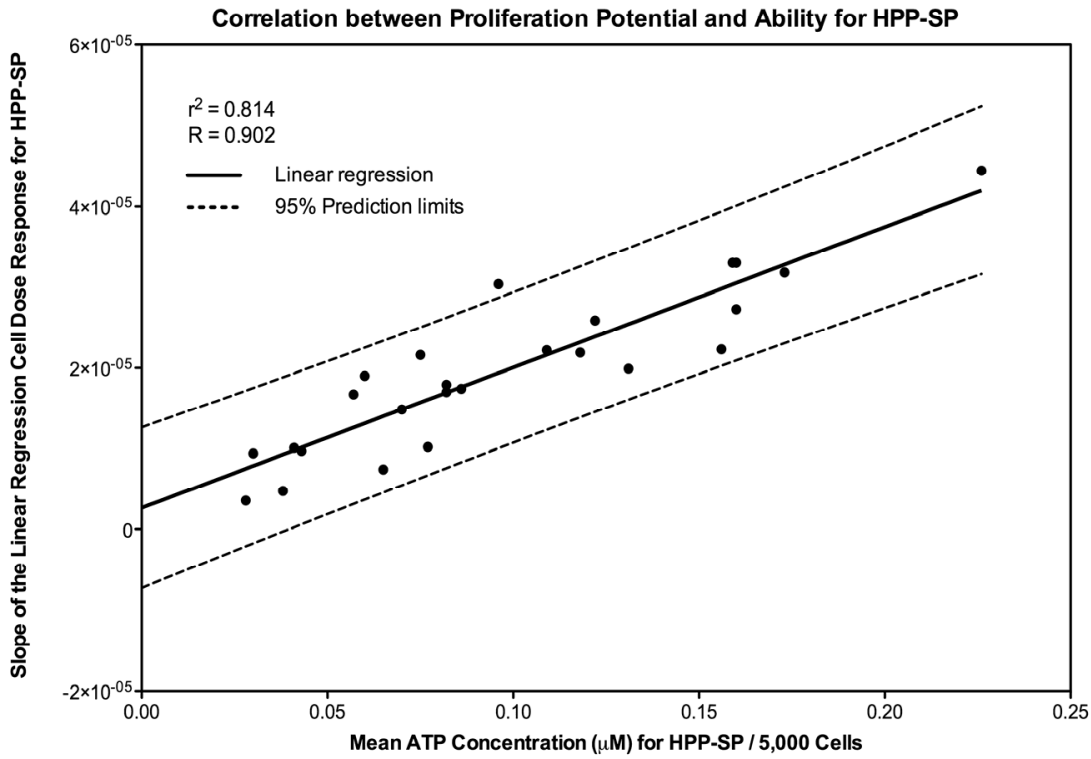

Fig. 4. Correlation Between Proliferation Potential (Potency) and Proliferation Ability (Quality) for CFC-GEMM and HPP-SP Stem Cells from Umbilical Cord Blood. 
Figures $4 \mathrm{~A}$ and $4 \mathrm{~B}$ show the correlation of ATP concentrations at 5,000 cells/well with the slope of the UCB dose response for both CFC-GEMM and HPP-SP stem cell populations. The correlation coefficient (R) for HPP-SP was greater than that for CFC-GEMM, but the correlation for both stem cell populations was statistically significant $(p<0.001)$. The relationship between stem cell potency and quality is an indication that both parameters have to be taken into consideration when defining release criteria. Although stem cell quality could be ascertained for sample 10, insufficient cells were available to measure stem cell potency. Insufficient cells for samples 18 and 26 were also the reason why potency could not be determined for the HPP-SP stem cell population.
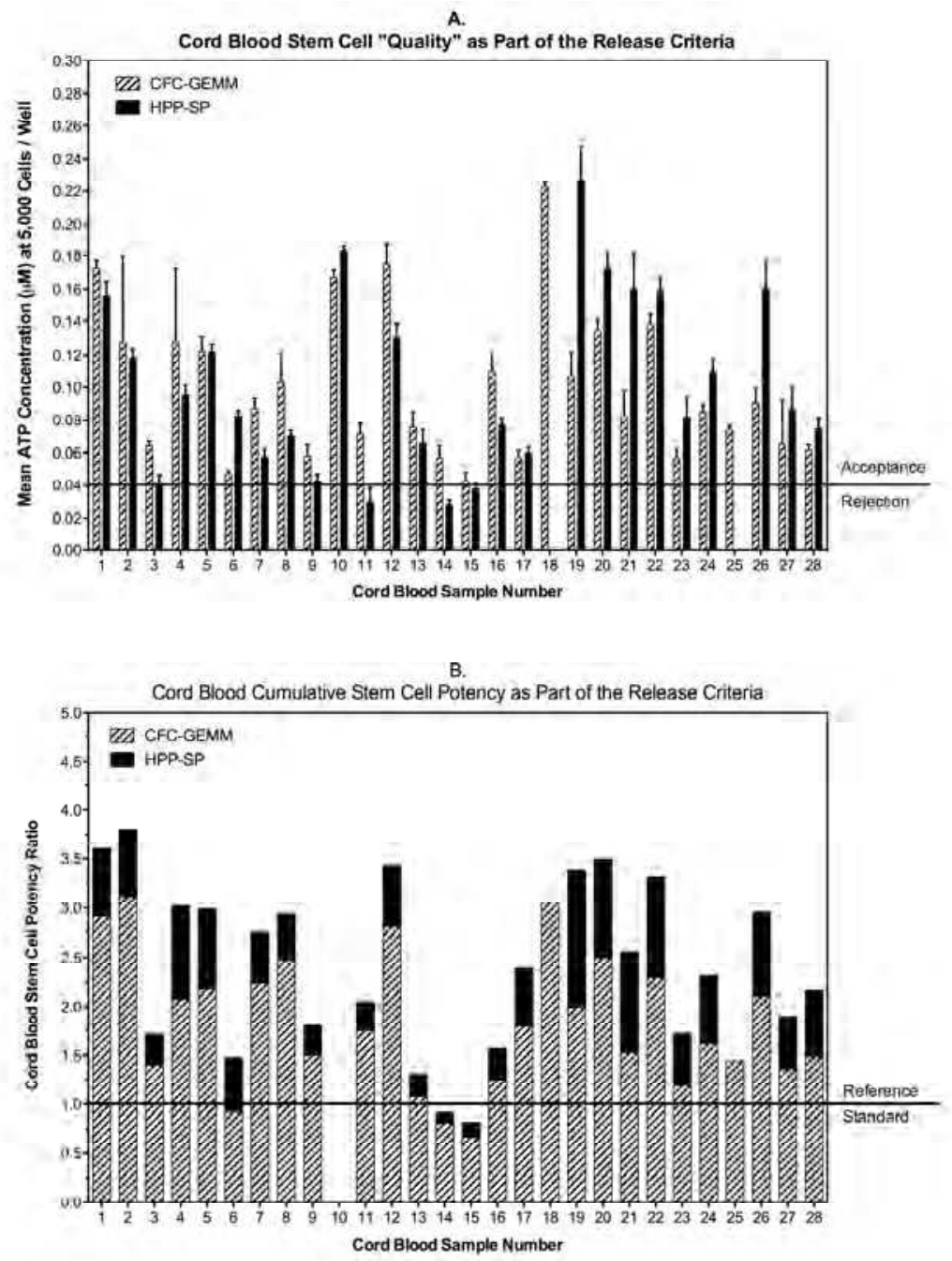

Fig. 5. Combining Umbilical Cord Blood Stem Cell Potency and Quality to Provide Release Criteria. 
Figure 5A shows the stem cell quality (proliferation ability at a specific cell dose) and Fig. $5 \mathrm{~B}$, the cumulative stem cell potency ratio (proliferation potential measured as the slope of the linear regression of the cell dose response and compared to that of the reference standard) for each of the stem cell populations. Samples 18 and 25 only show the potency for the CFC-GEMM populations since insufficient cells were available to measure the potency of the more primitive HPP-SP population. For 21 of the samples, stem cell quality of both populations was greater than the arbitrary ATP concentration cutoff level of $0.04 \mu \mathrm{M}$, below which cells cannot sustain proliferation. The same 21 samples also exhibited a cumulative potency above the RS potency of 1 . Sample 6 exhibited a CFC-GEMM potency below the RS, while sample 13 demonstrated a CFC-GEMM potency slightly greater than the RS. However, the additional potency provided by the HPP-SP stem cell populations increased the cumulative potency above that of the RS.

It is now possible to consider the interpretation of the results. Samples 14 and 15 pose an interesting anomaly. The CFC-GEMM quality is below the ATP concentration cutoff point for both samples and slightly greater than the cutoff point for HPP-SP. However, both samples exhibit a cumulative potency below the RS. These results would indicate that both sample 14 and 15 would exhibit limited or no engraftment potential. From Table 1, the time to neutrophil engraftment for sample 14 was only 19 days while that for sample 15 was 31 days. Platelet engraftment was 183 and 122 days for sample 14 and 15, respectively. Therefore, these two samples did not agree with the reported clinical outcome. Table 1 also shows that samples 13 and 18 did not engraft. As described above, sample 13 exhibited a CFC-GEMM potency that was in a questionable range and may not have provided the necessary short-term engraftment and reconstitution. In contrast, sample 18, appeared to exhibit sufficient CFC-GEMM quality and potency, although insufficient cells did not allow information to be obtained for the primitive HPP-SP stem cell population. Despite the four sample outliers, the assay exhibits an accuracy of greater than $85 \%$. Nevertheless, further studies that correlate in vitro data with more detailed clinical outcome for both engraftment and reconstitution would be prudent to ascertain a range for both stem cell quality and potency that would improve the accuracy of the assay.

\subsection{Correlation between the ATP concentration and TNC, MNC, viability, CD34}

There was no correlation between the ATP concentration for both cord blood stem cell populations with either dye exclusion viability or $\mathrm{CD} 34^{+}$counts. This was to be expected since neither viability nor CD34 membrane expression are cell functionality or proliferation markers. However, ATP concentration did correlate with both the TNC and MNC, but only when calculated on a per kilogram patient body weight basis. These results are shown in Fig. 6A for TNC and 6B for MNC. In both cases, the ATP concentration was calculated based on the patient body weight of the number of cells transplanted. The results in Fig. 6A demonstrate that when TNC is used, a strong correlation is obtained for the CFC-GEMM, but although still statistically significant, the primitive HPP-SP stem cell population exhibited a lower correlation coefficient. In contrast, Fig. $6 \mathrm{~B}$ shows that the correlation between the ATP concentration and the MNC, both based on kilogram body weight, for CFC-GEMM and HPP-SP is highly significant with lower variation compared to the TNC values. The results clearly demonstrate that the greater the number of cells transplanted, the greater the number of stem cells transplanted that can exhibit proliferation ability. However, 
the results also demonstrates that using the mononuclear cell count rather than total nucleated cell count produces a better estimate for the stem cell response. However, cell counts alone cannot be used as a potency assay and cannot replace the information and value provided by a standardized cell functionality assay.

A.

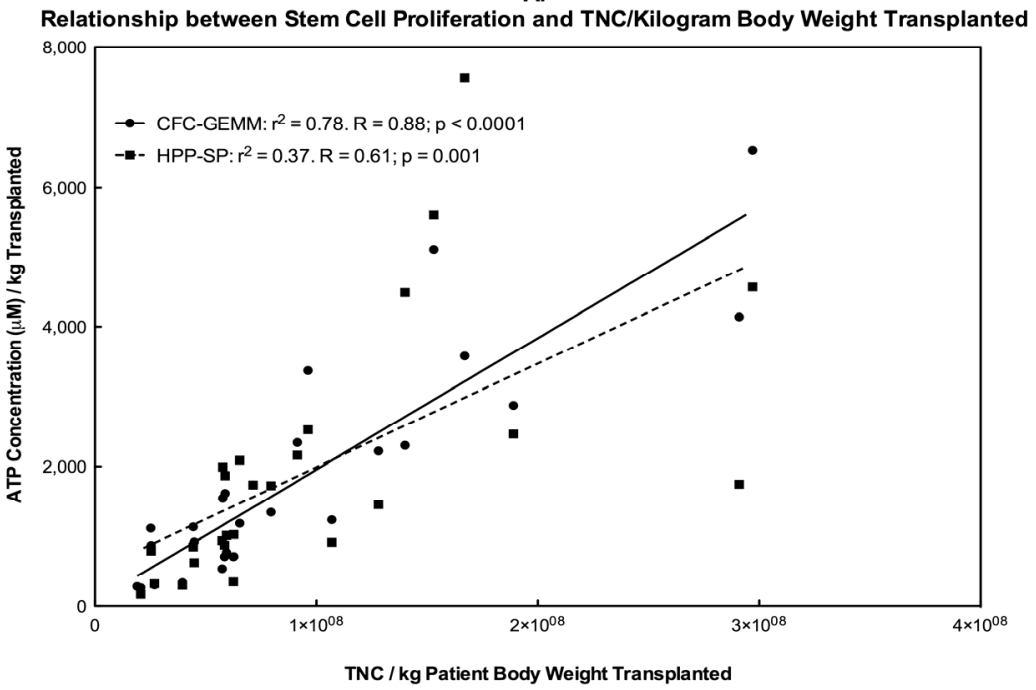

B.

Relationship between Stem Cell Proliferation and MNC/Kilogram Body Weight Transplanted

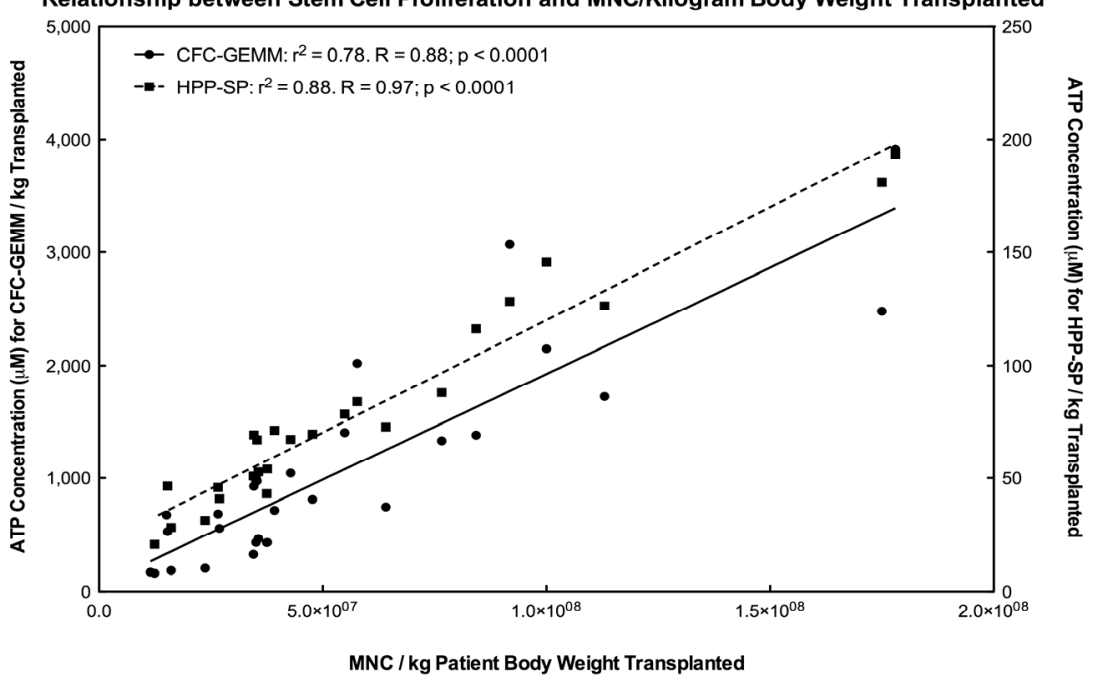

Fig. 6. Correlation between ATP Concentration as a Measure of Stem Cell Proliferation and the Number of Cord Blood Cells Transplanted Expressed as either Total Nucleated Cell Counts (TNC) or Mononuclear Cell Counts (MNC)/Kilogram Body Weight. 


\section{Discussion}

For biopharmaceutical products, potency is measured by comparing the dose response to that of an established RS (Thorpe et al. 1999; Lansky, 1999; FDA, 2011). For these materials, a parallel dose response to that of the RS should be obtained (Thorpe et al, 1999; Gottscalk \& Dunn, 2005; Jonkman \& Sidik, 2009). Lack of parallelism indicates either contamination or a different material to that of the RS. When the dose response curves are parallel to the RS, the horizontal displacement to the left or right indicates a greater or lower potency, respectively. The dose of the compound can be compared and, if necessary, adjusted to that of the reference standard. In this way, the same dose can always be used with compound batches of different potency.

Cells, in particular, stem cells, pose significant differences and challenges to this paradigm. First, unlike biopharmaceutical products, where relatively large quantities of the material would be available to establish several batches of reference standards, it might be extremely difficult to establish cell reference standards (Strong et al. 2009; Rayment \& Williams, 2010). There are several alternatives to establishing reference standards for cell therapeutics that have already been discussed above. However, a prerequisite for establishing reference standards and to compare results within and between laboratories is the use of a standardized and validated assay that is sufficiently robust so that it can be transferred and established in different laboratories. Lack of such an assay has been the reason why laboratories have not been able to directly compare processing, cryopreservation and thawing procedures for hematopoietic and other stem cell therapeutic products prior to use.

It might be argued that the present study should have been performed in parallel with the CFU assay. This has been the functional assay used previously in hematopoietic stem cell processing laboratories and is still used by the cord blood community today. More recently, the CFU assay has been suggested as a potency assay (Page et al. 2011a, 2011b), in addition to other parameters normally measured. These include total nucleated cell count (TNC), viability and CD34 membrane expression (FDA, 2009). There were three reasons for not performing parallel studies using the CFU assay. First, the ATP bioluminescence assay was originally derived from the methylcellulose CFU assay. Unlike the CFU assay, however, the ATP assay has undergone several major technical advances culminating in the assay used for the present study. It was also previously shown that even the methylcellulose-free format used in this study is not only equivalent to the original CFU assay, but is clearly a more reliable, reproducible and robust assay (Rich, 2007, Reems et al, 2008). Furthermore, lower sensitivity and precision (high variations) of the CFU assay, coupled with the lack of standardization (see below), would have resulted in inconclusive results. Second, unlike the CFU assay, the ATP assay can and has been validated in compliance with bioanalytical regulatory requirements (FDA, 2001). Furthermore, for an assay to be a potency assay, the regulatory agencies require demonstration of specific assay characteristics (FDA, 2011). Assay validation is just one of these characteristics, but to validate an assay, standards and controls are required. The CFU assay lacks standards and controls and cannot be validated according to regulatory requirements. Finally, it is often assumed that the CFU assay measures proliferation, whereas the CFU assay is actually a clonogenic differentiation assay. Proliferation is certainly involved in the formation of hematopoietic colonies. However, the colonies produced in methylcellulose are identified and counted by the ability of the cells producing the colonies to differentiate and mature. Therefore, the CFU assay detects 
differentiation ability and/or potential, but does not measure a parameter that directly correlates with the stem cell proliferation process. Based on these and other characteristics (discussed below), the CFU assay was not considered as a comparison assay for this study.

Many factors affect the quality and potency of a cellular product. First, proportions of different stem cell populations originally present in the umbilical cord blood, their quality and potency, are an inherent property of the tissue. Second, the procedures used to collect and store the cells prior to processing can affect quality and potency. Third, different stem cell processing, cryopreservation and thawing procedures not only affect quality and potency, but the proportion of stem cells remaining in the product. Finally, the decision process to use a particular product should be based on trusted results that can only be obtained from an assay(s) that is quantitative, standardized and validated to measure quality and potency of the active stem cell ingredients.

The stem cell potency assay described above is based on performing a minimum 3-point cell dose response and comparing the slope of the resulting linear regression to that of a RS of the same material. Comparison of cell dose response slopes to calculate the potency ratio was used for two reasons. First, measurement of potency of a biopharmaceutical compound usually relies on establishing parallelism between the sample and RS dose response curves. When the linear portions of the dose response curve are parallel, not only is this an indication that the sample and RS are of the same material, but also allows the potency ratio to be calculated from the horizontal displacement between the two dose response curves. If cells, and stem cells in particular, exhibit parallel cell dose response curves, this is an indication that both the sample and RS stem cells demonstrate a similar "stemness" or primitiveness. The resulting parallel displacement indicates a difference, not in potency, but in stem cell number between the sample and RS. Since hematopoiesis is a continuously proliferating system and the cells are continuously in flux, it follows that very few hematopoietic stem cell samples will exhibit exactly the same degree of primitiveness to the cells in the RS. Therefore potency measurement by parallelism will not provide a general procedure to calculate the potency ratio. Since an assay should show linearity within a specific cell concentration range, measuring the slope of the cell dose response not only demonstrates assay linearity characteristics, but also provides a direct measurement of stem cell primitiveness and proliferation potential, which in turn, is equivalent to stem cell potency. By comparing the slope of the sample cell dose response with that of the RS, the potency ratio can be calculated. Depending on the stem cell population detected, more primitive stem cells will show a steeper slope to that of mature stem cells. This procedure can then be used for any proliferating cell population. A 3-point cell dose response is the minimum number of data points that can be used to perform linear regression analysis. Although a larger number of points could also be used and would be more accurate, it was necessary to take into account that for hematopoietic tissues (and other cellular therapeutic products), cell availability is limited. Potency measurement should be performed just prior to use, since it is related to the dose that is to be administered. From a practical viewpoint, a cord blood potency determination would be performed on the limited number of cells thawed in a segment used for confirmatory testing prior to the cord blood unit being transplanted. Several publications have shown, using TNC, viability, CD34 and CFU, that segments of cryopreserved cord blood used for confirmatory testing are a representative sample of the cells in the cord blood unit (Goodwin et al. 2003; Solves et al. 2004, Rodriguez et al. 2005; Page et al. 2011b). However, in all of these cases, the potency of the active ingredients, i.e. the stem cells, were not taken into account. 
A potency assay requires that all active ingredients be measured (FDA, 2011). This is relatively easy for a biopharmaceutical compound, but is impossible for a continuously proliferating system such as hematopoiesis. Although a hematopoietic stem cell tissue may contain many different cell types, the stem cells are the only cells responsible for engraftment and reconstitution. The stem cells are therefore the active ingredients for which the potency must be measured. Since the hematopoietic stem cell compartment consists of a continuum of stem cells and assays are not yet available to test each and every stem cell subpopulation, the regulatory requirement to measure all active ingredients, cannot be met at the present time. As an alternative, the quality and potency of a minimum of two different stem cell populations have been determined; the primitive HPP-SP and the more mature CFC-GEMM stem cell populations. As shown in Fig. 5, the potency of a single stem cell population would be insufficient and could lead to a false interpretation of the results. As also demonstrated in Fig. 5, even a minimum of two stem cell populations may result in a false interpretation, but the accuracy is significantly greater than if the potency of only one stem cell population was measured. It is certainly possible to reliably and reproducibly measure the quality and potency of more than two stem cell populations with present technology. However, this has to be weighed against the use of larger numbers of cells and the costs associated with testing. It should also be emphasized that potency and quality testing need to be performed on the cryopreserved sample intended for use. They provide predictive information for release. It is therefore reasonable to pose the question, is it preferable to use more cells for a predictive assay that might ensure stem cell functionality, engraftment potential and growth than to use fewer cells and not perform any assay?

In this respect, it is worth returning to the tests and assays presently used to characterize the cells in the processing laboratory. These are TNC, viability and viable CD $34^{+}$counts. These three parameters have been designated as measurements of potency for umbilical cord blood (FDA, 2009), despite the fact that they do not comply with the necessary regulations for a potency assay, especially since none of the parameters are functional assays and measure the active ingredients. Of the three parameters listed above, probably the most important is the TNC dose. However, the TNC count includes a large proportion of cells that play no role in engraftment. Inclusion of these cells actually results in a dilution of the active stem cell ingredients. In contrast to using TNC, removing most of the unnecessary cells to produce an MNC fraction that contained the pool of stem cells, it was possible to demonstrate that the MNC dose used for transplantation exhibited a greater correlation with the ATP dose for both the CFC-GEMM and HPP-SP stem cell populations (Fig. 6). This result illustrates that the ATP concentration can be used as a measure of stem cell dose, which in turn is related to the potency ratio.

The potency predicts the dose of the product for the intended use. The potency of a stem cell product should predict the dose of stem cells required to achieve engraftment. In other words, stem cell potency predicts engraftment potential. This should not be confused with, and is not the same as time to engraftment. If the slope of the stem cell linear regression dose response curves or the stem cell potency ratios provided in Table 1 is plotted against the time to engraftment, no correlation will be obtained. This is because potency is entirely dependent upon stem cell proliferation potential, while time to engraftment is dependent upon the differentiation and maturation of hematopoietic progenitor cells into neutrophils, 
platelets and erythrocytes. This is the reason why the presence and number of progenitor cell colonies counted in the CFU assay, especially GM-CFC and Mk-CFC, relates to the appearance and number of neutrophils and platelets in the circulation of the patient (Page et al. 2011a).

Although the number of UCB transplants has increased almost exponentially since the first published UCB transplant in 1989 (Gluckman et al. 1989), approximately 20\% of patients receiving an unrelated UCB transplant exhibit graft failure (Page et al. 2011a, 2011b). This has, in part, been attributed to inadequate UCB potency (Page et al. 2011a, 2011b). Previous publications have focused on the need for standardized laboratory procedures (Rich, 1997; Wagner E et al. 2006; Brand A et al. 2008). A recent publication by Spellman et al. (2011) discusses problems facing the cord blood community and the guidelines and requirements for "standardized testing methodologies" to be established. The cell-based, ATP bioluminescence assay platform described in this communication to measure both stem cell potency and quality and, in addition, help define release criteria, constitutes the next generation of assays that addresses all of the necessary requirements including, but not limited to, standardized methodology, reproducibility with limited variability between testing sites, automated testing outputs, high throughput capability and rapid turnaround time.

\section{Conclusions}

It is often the case that an assay will be generic and adapted to fit the intended application. The present communication describes an assay that has been specifically designed and validated for the purpose of measuring stem cell quality and potency for hematopoietic cellular therapeutic products derived from mobilized peripheral blood, umbilical cord blood and even bone marrow (data not shown). A similar potency and quality assay has also been developed for mesenchymal stem cells. The assays incorporate an instrument-based, biochemical marker in the form of ATP, the concentration of which is directly proportional to the proliferation ability and potential of the stem cell populations being measured. The bioluminescence signal detection system is the most sensitive, non-radioactive readout available allowing the assay to incorporate external standards and controls. The implementation of a fully compliant potency and quality assay specific for hematopoietic stem cell products should not only help standardize cell processing procedures, but also reduce the risk of graft failure and improve safety and efficacy for the patient.

\section{References}

Botnick LE, Hannon EC, Hellman S. (1979). Nature of the hematopoietic stem cell compartment and its proliferative potential. Blood Cells. 5:195-210.

Brand A, Eichler H, Szczepiorkowski ZM, Hess JR, Kekomaki E, McKenna DH, PamphilionD, Reems J, Sacher RA, Takahashi TA, van der Watering LM (2008). Viability does not necessarily reflect the hematopoietic cell potency of a cord blood unit: results ofan interlaboratory exercise. Transfusion. 48:546-549.

Broxmeyer HE, Douglas GW, Hangoc C, Cooper S, Bard J, English D, Arny M, Thomas L, Boyse EA. (1989) Human umbilical cord blood as a potential source of 
transplantable hematopoietic stem/progenitor cells. Proc Natl Acad Sci USA 86:3828-3832.

Charbord P. (1994). Hemopoietic stem cells: analysis of some parameters critical for engraftment. Stem Cells. 12:545-62.

Civin CI, Almeida-Porada G, Lee MJ, Olweus J, Testappen LW, Zanjani ED. (1996). Sustained, retransplantable, multilineage engraftment of highly purified adult human bone marrow stem cells in vivo. Blood. 88:4102-9.

DeLong ER, Vernon WB, Bollinger RR. (1985). Sensitivity and specificity of a monitoring test. Biometrics. 41:947-58.

Duggan PR, Guo D, Luider J, Auer I, Klassen J, Chaudhry A, Morris D, Glueck S, Brown CB, Russell JA, Stewart DA. (2000). Predictive factors for long-term engraftment of autologous blood stem cells. Bone Marrow Transplant. 26:1299-304.

European Medicines Agency (EMA) (2008). Guideline on potency testing of cell based immunotherapy medicinal products for the treatment of cancer. http:/ / www.tga.gov.au/pdf/euguide/bwp27147506en.pdf.

FDA Guidance for Industry. (2009). Minimally manipulated, unrelated allogeneic placental/umbilical cord blood intended for hematopoietic reconstitution for specified indication.

http://www.fda.gov/downloads/BiologicsBloodVaccines/GuidanceCompliance RegulatoryInformation/Guidances/Blood/UCM187144.pdf.

Gluckman E, Broxmeyer HA, Auerbach AD, Friedman HS, Douglas GW, Devergie A, Esperou H, Thierry D, Socie G, Lehn P, Scott Cooper BS, English D, Kurtzberg J, Bard J, Boyse EA. (1989). Hematopoietic reconstitution in a patient with Fanconi's anemia by means of umbilical-cord blood from an HLA-identical sibling. N Engl J Med. 321:1174-1178.

Goodwin HS, Grunzinger LM, Regan DM, McCormick KA, Johnson CE, Oliver DA, Muecki KA, Alonso JM, Wall DA. (2003). Long term cryostorage of UC blood units: ability of the integral segment to confirm both identity and hematopoietic potential. Cytotherapy. 5:80-86.

Gottschalk PG, Dunn JR. (2005). Measuring parallelism, linearity, and relative potency in bioassay and immunoassay data. J Biopharma Stat. 15:437-463.

Haas R, Ho AD, Bredthauer U, Cayeux S, Egerer G, Knauf W \& Hunstein W. (1990). Successful autologous transplantation of blood stem cells mobilized with recombinant human granulocyte-macrophage colony-stimulating factor. Exp Hematol. 18:94-98.

Hall KM \& Rich IN. (2009). Bioluminescence assays for assessing potency of cellular therapeutic products, In: Cellular Therapy: Principles, Methods and Regulations, Areman EM \& Loper K, 581-591. AABB. ISBN 978-1-56395-296-8. Bethesda, MD.

Jonkman JN, Sidik, K. (2009). Equivalence testing for parallelism in the four-parameter logistic model. J Biopharma Stat. 19:818-37.

Koerbling M, Holle R, Haas R, Knauf W, Doerken B, Ho AS, Kuse R, Pralle H, Fliedner TM, Hunstein W. (1990). Autologous blood stem cell transplantation in patients with 
advanced Hodgkin's disease and prior radiation to the pelvic site. J Clin Oncol. 8:978-985.

Lansky D. (1999). Validation of bioassay for quality control. Dev Biol Stand. 97:157-68.

Leung W, Ramirez M, Civin CI. (1999). Quantity and quality of engrafting cells in cord blood and autologous mobilized peripheral blood. Biol Blood Marrow Transplant. 5:69-76.

National Marrow Donor Program (NMDP). http://www.marrow.org/PHYSICIAN/URD_Search_and_Tx/Number_of_Alloge neic_Tx_Perfor/index.html\#grafts.

Olaharski AJ, Uppal H, Cooper M, Platz S, Zabka TS, Kolaja KL. (2009). In vitro to in vivo concordance of a high throughput assay for bone marrow toxicity across a diverse set of drug candidates. Toxicol Let 188:98-103.

Page KM, Zhang L, Mendizabai A, Weasse S, Carter S, Gentry T, Balber E, Kurtzberg J. (2011a). Total colony-forming units are a strong, independent predictor of neutrophil and platelet engraftment after unrelated umbilical cord blood transplantation: A single-center analysis of 435 cord blood transplants. Biol Blood Marrow Transplant. (Jan 28. Epub ahead of print).

Page KM, Zhang L, Mendizabai A, Weasse S, Carter S, Shoulars K, Gentry T, Balber E, Kurtzberg J. (2011b). The cord blood Apgar: a novel scoring system to optimize selection of banked cord blood grafts for transplantation. (2011b). Transfusion. (Aug. 2. Epub ahead of print).

Pasquini MC \& Wang Z. (2010). Current use and outcome of hematopoietic stem cell transplantation. CIBMTR Summary Slides, 2010. http://www.cibmtr.org/ReferenceCenter/SlidesReports/SummarySlides/pages/ index.aspx\#CiteSummarySlides.

Picardi A, Arcese W. (2010). Quality assessment of cord blood units selected for unrelated transplantation: a transplant center perspective. Transfus Apher Sci. 42:289-97.

Querol S, Gomez SG, Pagliuca A, Torrabadella M, Madrigal JA. (2010). Quality rather than quantity: the cord blood bank dilemma. Bone Marrow Transplant. 45:970-8.

Rayment EA \& Williams DJ. (2010). Concise rewiew: Mind the gap: challenges in characterizing and quantifying cell- and tissue-based therapies for clinical translation. Stem Cells. 28:996-1004.

Reems J-A, Hall KM, Gebru LH, Taber G, Rich IN. (2008). Development of a novel assay to evaluate the functional potential of umbilical cord blood progenitors. Transfusion. 48:620-628.

Rich IN \& Hall KM. (2005). Validation and development of a predictive paradigm for hemotoxicity using a multifunctional bioluminescence colony-forming proliferation assay. Tox Sci. 87:427-41.

Rich IN, Kubanek B. (1982). The effect of reduced oxygen tension on colony formation of erythropoietic cells in vitro. Brit J Haematol. 52:579-88.

Rich IN. (1997). Standardization of the CFU-GM assay using hematopoietic growth factors. J. Hematother. 6:191-193. 
Rich IN. (2003). In vitro hematotoxicity testing in drug development: A review of past, present, and future applications. Curr Opinion Drug Disc Devel. 6:100-109.

Rich IN. (2007). High-throughput in vitro hemotoxicity testing and in vitro cross-platform comparative toxicity. Expert Opin. Drug Metab Toxicol. 3:295-307.

Rodriguez L, Garcia J, Querol S. (2005). Predictive utility of the attached segment in the quality control of a cord blood graft. Biol Blood Marrow Transplant. 11:247251.

Santos GW, Sensenbrenner LL, Burke PJ, Mullins GM, Vias WB, Tutschka PJ \& Slavin RE. (1972). The use of cyclophosphamide for clinical transplantation. Transplant Proc. 4:559-564.

Santos GW. (1983). History of bone marrow transplantation. Clin Haematol. 12:611-639.

Sohn SK, Kim JG, Seo KW, Chae YS, Jung JT, Suh JS, Lee KB. (2002). GM-CSF-based mobilized effect in normal healthy donors for allogeneic peripheral blood stem cell transplantation. Bone Marrow Transplant. 30:81-86.

Solves P, Planelles D, Mirabet V, Blasco I, Carbonell-Uberos F, Soler MA, Roig RJ. (2004) Utility of bag segment and cryovial samples for quality and confirmatory HLA typing in umbilical cord blood banking. Clin Lab Haematol. 26:413-418.

Spellman S, Hurley CK, Brady C, Phillips-Johnson L, Chow R, Laughlin M, McMannis J, Reems J-A, Regan D, Rubinstein P, Kurtzberg J. (2011). Guidelines for the development and validation of new potency assays for the evaluation of umbilical cord blood. Cyotherapy (March, Epub ahead of print).

Strong M, Farrugia A \& Rebulla P. (2009). Stem cell and cellular thereapy developments. Biologicals. 37:103-107.

Thomas ES, Buckner CD, Banaji M, Clift RA, Fefer A, Flournoy N, Goodell BW, Hickman RO, Lerner KG, Neiman PE, Sale GE, Sanders JE, Singer J, Stevens M, Storb R \& Weiden PI. (1977).One hundred patients with acute leukemia treated by chemotherapy, total body irradiation, and allogeneic marrow transplantation. Blood. 49:511-533.

Thorpe R. Wadhwa M, Page C, Mire-Sluis A. (1999). Bioassays for the characterization and control of therapeutic cytokines; determination of potency. Dev Biol Stand. 97:6171.

Till JE \& McCulloch EA. (1971). A direct measurement of the radiation sensitivity of normal mouse bone marrow cells. Radiat Res. 175:145-149.

U.S. Food and Drug Administration (FDA) (2001). Guidance for Industry. Bioanalytical method validation.

http://www.fda.gov/downloads/Drugs/GuidanceComplianceRegulatoryInfor mation/Guidances/ucm070107.pdf.

U.S. Food and Drug Administration (FDA) (2011). Guidance for Industry. Potency tests for cellular and gene therapy products.

http://www.fda.gov/downloads/BiologicsBloodVaccines/GuidanceComplianceR egulatoryInformation/Guidances/CellularandGeneTherapy/UCM243392.pdf.

Wagner E. Duval M, Dalle JH, Morin H, Bizier S, Champagne J, Champagne MA. (2006) Assessment of cord blood unit characteristics on the day of transplant: comparison with data issued by cord blood banks. Transfusion. 46: 1190-1198. 
Zubair AC, Kao G, Daley H, Schott D, Freedman A, Ritz J. (2006). CD34(+) CD38(-) and CD34(+) HLA-DR(-) cells in BM stem cell grafts correlate with short-term engraftment but have no influence on long-term hematopoietic reconstitution after autologous transplantation. Cytotherapy. 8:399-407. 


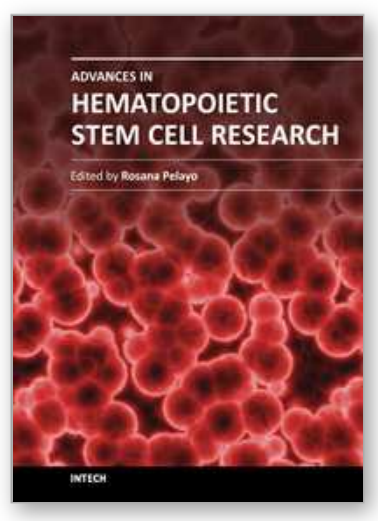

\author{
Advances in Hematopoietic Stem Cell Research \\ Edited by Dr. Rosana Pelayo
}

ISBN 978-953-307-930-1

Hard cover, 464 pages

Publisher InTech

Published online 27, January, 2012

Published in print edition January, 2012

This book provides a comprehensive overview in our understanding of the biology and therapeutic potential of hematopoietic stem cells, and is aimed at those engaged in stem cell research: undergraduate and postgraduate science students, investigators and clinicians. Starting from fundamental principles in hematopoiesis, Advances in Hematopoietic Stem Cell Research assemble a wealth of information relevant to central mechanisms that may regulate differentiation, and expansion of hematopoietic stem cells in normal conditions and during disease.

\title{
How to reference
}

In order to correctly reference this scholarly work, feel free to copy and paste the following:

Karen M. Hall, Holli Harper and Ivan N. Rich (2012). Hematopoietic Stem Cell Potency for Cellular Therapeutic Transplantation, Advances in Hematopoietic Stem Cell Research, Dr. Rosana Pelayo (Ed.), ISBN: 978-953307-930-1, InTech, Available from: http://www.intechopen.com/books/advances-in-hematopoietic-stem-cellresearch/hematopoietic-stem-cell-potency-for-cellular-therapeutic-transplantation

\section{INTECH}

open science | open minds

\section{InTech Europe}

University Campus STeP Ri

Slavka Krautzeka 83/A

51000 Rijeka, Croatia

Phone: +385 (51) 770447

Fax: +385 (51) 686166

www.intechopen.com

\section{InTech China}

Unit 405, Office Block, Hotel Equatorial Shanghai

No.65, Yan An Road (West), Shanghai, 200040, China

中国上海市延安西路65号上海国际贵都大饭店办公楼 405 单元

Phone: +86-21-62489820

Fax: +86-21-62489821 
(C) 2012 The Author(s). Licensee IntechOpen. This is an open access article distributed under the terms of the Creative Commons Attribution 3.0 License, which permits unrestricted use, distribution, and reproduction in any medium, provided the original work is properly cited. 